\title{
PENGARUH MODEL PEMBELAJARAN SENTRA BAHAN ALAM TERHADAP KEMAMPUAN SAINS DAN BERBICARA ANAK KELOMPOK B DI TAMAN KANAK-KANAK
}

\author{
AJENG PUTRI PRATIWI ${ }^{1}$ - RIKA KURNIA ${ }^{2}$ - NOPIANA
}

\author{
Edukasi Mitra Grafika \\ Jl. Tamalate III No 45 Perumnas Makassar \\ Email: ajengputripratiwi@gmail.com, rikakurnia.budiman@co.id, \\ sukmariahnopie@gmail.com
}

\begin{abstract}
This research aimed to examine (1) the effect of natural centered model of learning method for group B children scientific skills (2) the effect of natural centered model of learning method for group B children speaking skills (3) the effect of natural centered model of learning method for group B children scientific and speaking skills.This research uses a quantitative approach which is using Nonequivalent Control Group Design. The reserch was conducted in group B at TK PGRI 3 Pandaan and TK PKK V Pandaan. Experimental groups totaling 44 children and 40 children for controlling groups. The research data are collected using observation method, documentation and observation guide used to collect data about scientific and speaking skills. Analysis data is using ANOVA and MANOVA statistic test with SPSS 21.0. This research results show that (1) Natural centered model of learning method is effecting group B children scientific skills, it is evident from the ANOVA test results demonstrate the value of Fcount is 163,661 with sig. 0,000 smaller than 0.05. (2) Natural centered model of learning method is effecting group B children speaking skills it is evident from the ANOVA test results demonstrate the value of Fcount is 61,992 with sig. 0,000 smaller than 0.05. (3) Natural centered model of learning method is effecting group B children scientific and speaking skills, it is evident from the ANOVA test results demonstrate the value of Fcount or wilks'lambada is 163,661 with sig. 0,000 smaller than 0.05. Because the third hypothesis states $<0.05$ then declared acceptable. According this research result, it can be concluded as (1) Natural centered model of learning method is effecting scientific skills (2) Natural centered model of learning method is effecting speaking skills (3) Natural centered model of learning method is effecting scientific and speaking skills. It will be advised to early childhood education institutes to apply Natural centered model of learning method as one of learning model which stimulate scientific and speaking skills on group B kindergarten children. Natural centered model of learning method is effecting group B children scientific skills.
\end{abstract}

Keywords: Natural centered, scientific and speaking

\begin{abstract}
Abstrak: Penelitian ini bertujuan untuk menguji (1) pengaruh model pembelajaran sentra bahan alam terhadap kemampuan sains anak kelompok B, (2) pengaruh model pembelajaran sentra bahan alam terhadap kemampuan berbicara anak kelompok B, (3) pengaruh model pembelajaran sentra bahan alam terhadap kemampuan sains dan kemampuan berbicara anak kelompok B. Penelitian ini menggunakan pendekatan penelitian kuantitatif dengan rancangan penelitian eksperimen semu Nonequivalent Control Group Design. Penelitian dilaksanakan pada kelompok B di TK PGRI 3 Pandaan dan TK PKK V Pandaan dengan kelompok eksperimen yang berjumlah 44 anak dan kelompok kontrol berjumlah 40 anak. Data penelitian dikumpulkan dengan metode observasi, dokumentasi dan pedoman observasi digunakan untuk mengumpulkan data tentang kemampuan sains dan berbicara. Analisis data menggunakan uji statistik ANOVA dan MANOVA dengan bantuan SPSS 21.0. Hasil penelitian menunjukkan bahwa (1) ada pengaruh model pembelajaran sentra bahan alam terhadap kemampuan sains, hal ini terbukti dari hasil uji ANOVA yang menunjukkan nilai $F_{\text {hitung }}$ sebesar 163,661 dengan nilai sig. 0,000 yang lebih kecil dari 0,05. (2)
\end{abstract}


pengaruh model pembelajaran sentra bahan alam terhadap kemampuan berbicara, hal ini terbukti dari hasil uji ANOVA yang menunjukkan nilai $F_{\text {hitung }}$ sebesar 61,992 dengan nilai sig. 0,000 yang lebih kecil dari 0,05. (3) pengaruh model pembelajaran sentra bahan alam terhadap kemampuan sains dan berbicara, hal ini terbukti dari hasil uji MANOVA yang menunjukkan nilai $F_{\text {hitung }}$ atau nilai wilks'lambda sebesar 0,317 dengan nilai sig. 0,000 yang lebih kecil dari 0,05. Karena ketiga hipotesis menyatakan $<0,05$ maka dinyatakan diterima. Berdasarkan hasil penelitian di atas, maka dapat ditarik kesimpulan sebagai berikut: (1) Model pembelajaran sentra bahan alam berpengaruh terhadap kemampuan sains (2) Model pembelajaran sentra bahan alam berpengaruh terhadap kemampuan berbicara (3) Model pembelajaran sentra bahan alam berpengaruh terhadap kemampuan sains dan berbicara. Selanjutnya disarankan pada lembaga anak usia dini untuk menerapkan model pembelajaran sentra bahan alam sebagai salah satu model pembelajaran untuk menstimulasi kemampuan sains dan berbicara pada anak kelompok B di Taman Kanak-kanak.

Kata Kunci: Sentra bahan alam, sains dan berbicara.

Pendidikan anak usia dini merupakan pijakan awal anak memperoleh pembinaan untuk mengoptimalkan potensi diri yang dimiliki, mengeksplorasi berbagai hal di lingkungan sekitar dan aktif melakukan kegiatan yang memotivasi untuk terus belajar memperoleh ilmu pengetahuan yang nantinya akan sangat berguna di kehidupan pada masa yang akan dating. Salah satu bentuk lembaga pendidikan anak usia dini yang berada pada jalur formal adalah Taman Kanak-kanak (TK) dengan rentang usia empat sampai enam tahun. Tujuan pendidikan di TK menurut Anderson (dalam Masitoh, dkk, 2012:1.8) bahwa pendidikan untuk anak usia dini khususnya TK perlu menyediakan berbagai kegiatan yang dapat mengembangkan berbagai aspek perkembangan yang meliputi kognitif, bahasa, sosial, emosi, fisik motorik, nilai agama dan moral.

Salah satu pembelajaran yang dapat menstimulasi perkembangan kognitif anak yaitu kegiatan pengenalan sains sederhana. Menurut Morisson (2012:270) Sains merupakan sarana ideal untuk mengembangkan pikiran anak-anak guna bertanya tentang dunia alam, sains mengajari anak mengapreasiasi keragaman kehidupan dan saling terkaitannya. Tahapan pembelajaran sains sederhana untuk anak usia dini dimulai dengan mengeksplorasi hal paling terdekat dengan dirinya, makanan, minuman, kegemaran, semua aktifitas tentang dirinya dengan bermain yang sesuai dengan tahapan perkembangannya. 
The National Council for Social Studies Standards (dalam Seefeld \& Wasik, 2008 :414) menyatakan bahwa ketrampilan yang sesuai dengan anak-anak dalam belajar mencangkup banyak hal, tetapi tidak terbatas pada ketrampilan penelitian, seperti mengumpulkan, mengorganisasikan, dan menafsirkan data serta ketrampilan berpikir seperti membandingkan dan menarik kesimpulan. Kedua pemaparan diatas menjelaskan bahwa anak belajar tentang dunia disekitar mereka melalui "learn by doing", belajar dengan melakukan, "learn by playing" belajar sambil bermain, "learn by exsperiment" belajar dengan bereksperimen. Sama halnya dengan sains " the best to learn science is to do science", cara terbaik belajar sains adalah dengan melakukan sains.

Menurut penelitian Eshach dan Fried (dalam Trundle, 2009) menyatakan bahwa pembelajaran sains pada anak usia dini sangat penting untuk aspek perkembagannya dan pendidikan anak usia dini merupakan awal bagi mereka untuk belajar sains. Selain itu aspek yang dapat dikembangkan dalam pembelajaran sauns untuk anak usia dini yaitu perkembangan motorik kasar dan halus, kognisi, sosial, bahasa dan moral.

Menurut Dodge, Colker, \& Heroman (dalam Jackman, 2012:175) Sains adalah sebuah kombinasi diantara process skills (bagaimana anak belajar) dan content ( apa yang anak pelajari). Dari pendapat tersebut mengungkapkan pentingnya perkembangan sains bagi anak usia dini yang merupakan bagian dari lingkup perkembangan kognitif yang mengkaji bagaimana anak belajar, apa yang dipelajari dan memungkinkan anak untuk memproses informasi baru melalui pengalaman konkret, mengeksplorasi, mengklasifikasi, merangsang rasa ingin tahu, menemukan berbagai hal, menjelaskan, mengelaborasi, dan mengevaluasi, sehingga anak dapat belajar tentang dunia disekitar mereka.

Aspek perkembangan lain yang penting untuk distimulasi yaitu perkembangan bahasa. Pengembangan bahasa diarahkan agar anak mampu menggunakan dan 
mengekspresikan pemikirannya perkembangan bahasa anak dengan menggunakan kata-kata. berkaitan dengan proses Kemampuan berbahasa yang pemerolehan bahasa yang berkembang setelah kemampuan dikendalikan dari luar diri anak. mendengar ialah kemampuan Chaer (2006:226) berbicara. Pentingnya anak mengungkapkan bahwa mengembangkan kemampuan dalam berbicara secara benar dan jelas agar dapat berinteraksi dan dapat dipahami oleh lingkungannya. Anak memerlukan pengalaman berkomunikasi dengan orang lain, dan melakukan interaksi sosial sementara orang dewasa disekitarnya menjadi model, pendengar, dan teman berbicara yang baik.

Vygotsky (dalam Dhieni, 2013:2.16) menyatakan bahwa bentuk bahasa pada dasarnya bersifat sosial, sedangkan Piaget memiliki kecenderungan pendapat bahwa perkembangan bahasa pada anak bersifat egosentris dan nonsosial.

Skinner (dalam Dhieni, 2013:2.16) memandang perkembangan bahasa dari sudut stimulus - respon, yang memandang berpikir sebagai proses internal bahasa mulai diperoleh dari interaksi dalam lingkungan. Dalam pandangan behaviorisme, perkembangan bahasa berkaitan dengan perkembangan sosial dan komunikasi. Pemerolehan bahasa tersebut berasal dari lingkungan berupa rangsangan yang berguna untuk perkembangan bahasa anak. Rangsangan (stimulus) dari lingkungan tertentu memperkuat kemampuan bahasa anak. Perkembangan bahasa dipandang sebagai suatu kemajuan dari pengungkapan verbal yang berlaku secara acak sampai ke kemampuan yang sebenarnya untuk berkomunikasi melalui prinsip pertalian S-R (stimulus-respon) dan proses peniruan-peniruan.

Tujuan perkembangan
bicara anak adalah untuk
menghasilkan bunyi secara verbal.
Kemampuan mendengar dan
membuat bunyi-bunyi verbal hal
pokok untuk menghasilkan suara
dalam berbicara. Kemampuan
berbicara anak berkembang melalui


pengucapan suku kata yang berbeda-beda dan diucapkan secara jelas. Lebih jauh lagi, kemampuan berbicara akan meningkat ketika anak dapat mengerti kata-kata baru dan memberikan pertanyaanpertanyaan.

Berdasarkan pendapat tersebut, perkembangan sains dan perkembangan berbicara anak sangat penting untuk diberikan stimulasi agar berkembang dengan optimal. Kedua perkembangan tersebut dapat dikembangkan melalui kegiatan belajar sambil bermain. Anak dapat berinteraksi dengan temannya, melakukan komunikasi dan melakukan proses berfikir dalam memecahkan masalah.

Sangat penting bagi pendidik memiliki kompetensi dalam memahami berbagai teori belajar, mengembangkan model pembelajaran, terampil menggunakan strategi belajar mengajar, membuat perencanaan pembelajaran dengan berbagai komponennya yang meliputi konsep, tujuan pembelajaran, tema, langkah-langkah pembelajaran, metode, alat/sumber belajar dan teknik evaluasi. Berbagai macam model pembelajaran dapat diterapkan di Taman Kanak-kanak diantaranya model pembelajaran sentra, model pembelajaran klasikal, model pembelajaran area dan model pembelajaran kelompok dengan sudut pengaman.

Salah satu model pembelajaran yang menarik dan banyak diimplementasikan di Taman Kanak-kanak saat ini ialah model pembelajaran sentra. Depdiknas mengungkapkan bahwa model pembelajaran sentra merupakan pendekatan penyelenggaraan PAUD yang berfokus pada anak yang dalam proses pembelajarannya berpusat di sentra main dan saat anak dalam lingkaran dengan menggunakan 4 jenis pijakan (scaffolding) untuk mendukung perkembangan anak, yaitu (1) pijakan lingkungan main (2) pijakan sebelum main (3) pijakan selama main dan (4) pijakan setelah main. Setiap sentra mendukung perkembangan anak dalam tiga jenis bermain, yaitu 
bermain sensorimotor, bermain peran, dan bermain konstruktivistik.

Asmawati

mengemukakan sentra adalah pembelajaran terpadu yang terbaik.

Sentra dapat membantu anak-anak mengembangkan seluruh kemampuannya secara bersamaan. Dalam sentra anak-anak belajar ketika mereka berpartisipasi aktif, mengamati, dan berinteraksi dengan anak lainnya.

Isabell (dalam Asmawati, 2008: 8.11) secara tradisional membagi sentra menjadi sentra rumah tangga, sentra balok, sentra seni, sentra pasir dan air, sentra perpustakaan, sentra musik dan lagu, sentra menulis, sentra sains dan alam. Dalam perkembangannya yang lebih modern, para pendidik dapat mengaplikasikan sentra-sentra baru sesuai dengan kebutuhan anak usia dini, salah satunya ialah sentra bahan alam.

Sentra bahan alam adalah tempat anak melakukan kegiatan dengan berbagai alat yang tepat sesuai dengan kebutuhan anak yang terdiri dari alat/bahan kering dan alat/bahan yang menggunakan air (Sujiono \&
Sujiono, 2010:85). Dalam pembelajaran di sentra bahan alam, anak belajar untuk memanfaatkan berbagai macam alat dan media yang terbuat dari alam atau yang telah tersedia dari alam. Hal ini sesuai dengan teori belajar konstruktivisme salah satu penerapan dalam pembelajaran adalah dengan memanfaatkan lingkungan sebagai sumber belajar dimana anak didorong untuk bereksplorasi dengan jalan menemukan suatu penemuan dan memcahkan hasil penemuan itu (Sagala, 2003:44).

Berdasarkan pemaparan tersebut, untuk mengembangkan kemampuan sains dan berbicara anak di Taman kanak-kanak dapat dilakukan dalam model pembelajaran sentra bahan alam dengan salah satu kegiatannyamenjadi penjual es buah. Hal ini dikarenakan bermain menggunakan media air sangat menyenangkan bagi anak, anak memperoleh pengetahuan umum dan sains tentang bahan-bahan alami dari alam yang dapat digunakan sebagai perasa manis, pewarna alami, dan alat yang digunakan selain itu anak dapat mengeksplorasi, mengobservasi dan 
melakukan percobaan sederhana dengan membuatnya sendiri.

Dengan menjadi penjual es buah, anak dapat menuangkan air kedalam gelas, mengamati perubahan warna dari percampuran santan, gula, susu, berbagai macam potongan buah yang semakin membuat menarik dan memberikan campuran es tube agar es buah yang dijual terasa lebih segar. Selain itu anak dapat juga memerasakan suhu dingin pada es dan mengamati perubahan es menjadi cair.

Sentra bahan alam dengan kegiatan menjadi penjual es buah juga dapat menstimulasi kemampuan berbicara pada anak, hal ini dikarenakan terjadi proses interaksi sosial sehingga terjalin komunikasi antara penjual dan pembeli. Anak melakukan dialog dengan pengalaman main yang menyenangkan sehingga anak dapat mengungkapkan pendapatnya, menjawab pertanyaan dari pembeli, menawarkan barang dagangannya, bertanya kepada pembeli dan bercerita tentang es buah yang dijualnya.
Berdasarkan hasil observasi di Taman Kanak-kanak yang menggunakan model pembelajaran sentra sudah cukup baik, namun dalam menstimulasi perkembangan sains pendidik masih kurang kreatif dalam merancang kegiatan bermain aktif dan eksploratif, pembelajaran sains masih banyak berupa konsep dan hafalan sehingga kurang melakukan berbagai macam percobaan sains sederhana, serta kurangnya menggunakan metode bermain yang memanfaatkan alat atau bahan alam sebagai sumber belajar. Begitu pula dalam menstimulasi kemampuan berbicara, anak kurang memperoleh kesempatan bertanya, mengungkapkan pendapat tentang apa yang telah dilakukan secara aktif dan interaktif.

Pada umumnya kegiatan pembelajaran yang menstimulasi kemampuan sains dan berbicara anak dapat dikembangkan di semua sentra, sesuai dengan kebutuhan anak dan tujuan pembelajaran. Namun dari semua sentra, model pembelajaran sentra bahan alam melalui kegiatan menjadi penjual es buah dianggap dapat lebih menstimulus kemampuan 
sains dan berbicara anak usia 5-6 tahun.

Melalui kegiatan menjadi penjual dan pembeli anak akan aktif bermain, anak saling berinteraksi dan mengkonstruksikan pemikirannya melalui pembelajaran yang memanfaatkan lingkungan sebagai sumber belajar, lebih mengeksplorasi kemampuan anak dalam berbicara, melakukan percobaan, mengamati, mengenal berbagai bahan alam yang dapat dimanfaatkan dan memberikan pengalaman belajar secara langsung. Oleh karena itu peneliti termotivasi mengadakan penelitian tentang pengaruh model pembelajaran sentra bahan alam terhadap perkembangan sains dan berbicara anak kelompok B di Taman Kanak-kanak.

\section{Langkah-langkah Pelaksanaan} Model Pembelajaran Sentra Bahan Alam

Secara umum langkah langkah pembelajaran di sentra bahan alam pasar dapat melalui langkahlangkah sebagai berikut:

\section{Penataan Lingkungan Main}

- Guru menyiapkan beberapa alat dan sumber belajar untuk bermain di sentra bahan alam, diantaranya: meja berukuran, 2x1 meter sebanyak 4 buahdankursi sebanyak 8 buah. Selanjutnya menyiapkan bahan bermain diantaranya: potongan buah semangka, nanas, melon, gula cair, sirup yang terbuat dari air nanas, sirup leci, agar-agar yang telah di potong dadu, susu, air putih, es tube. Sedangkan alatnya: 10 mangkuk batok kelapa, 10 gelas plastik, mangkuk tempat buah, sendok, teko air berukuran sedang, botol plastik sirup, tremos berukuran sedang, timba, cetakan buah.

- Semua alat dan bahan es buah di letakkan di atas meja yang disiapkan, kursi diletakkan dua untuk penjual dan sisanya untuk kursi tunggu pembeli.

\section{Penyambutan Anak}

- Guru

- Anak bermain bebas sambil menunggu kehadiran teman yang lain.

\section{Main Pembuka (Pengalaman Gerak}

\section{Kasar) ( \pm 15 menit)}

Anak dan guru berada di halaman bermain, bergandengan tangan 
membentuk lingkran besar, guru menyebutkan kegiatan pembuka yaitu membawa nampan berisi gelas berisi air melewati garis lurus dengan diiringi musik.

\section{Transisi $( \pm 10$ menit $)$}

- Setelah bermain anak diberi kesempatan untuk cuci tangan, cuci muka, cuci kaki, maupun buang air kecil di kamar mandi.

- Sambil menunggu anak minum atau ke kamar kecil, masingmasing siap ditempat bermain yang sudah disiapkan untuk kelompoknya masing-masing.

\section{Kegiatan awal}

- Pijakan Pengalaman Sebelum Bermain (15 menit).

- Anak duduk melingkar, memberi salam, dan menanyakan kabar anak-anak.

- Anak-anak untuk memperhatikan siapa saja yang tidak hadir (mempresensi).

- Berdo’a bersama.

- Guru menyampaikan tema hari ini yaitu macam-macam pedagang salah satunya ialah pedagang es buah yang sering dijumpai anakanak.
- Anak bercerita tentang pengalaman membeli es.

- Bernyanyi lagu "Pedagang es"

- Guru bercerita tentang berbagai aktivitas yang dilakukan di pedagang es buah, misalnya menyiapkan dagangannya, menjual es dan melayani pembeli.

- Guru mengenalkan tempat dan semua alat main yang sudah dipersiapkan di sentra bahan alam.

- Tanya jawab tentang aturan bermain menjadi pedagang es buah.

- Anak dipersilahkan bermain dengan tertib.

- Kegiatan inti di masing-masing kelompok

\section{Kegiatan Inti}

- Pijakan Pengalaman Selama Bermain (60 menit).

- Anak melakukan kegiatan sebagai penjual dan pembeli es buah sesuai aturan permainan yang telah disepakati bersama.

- Anak melakukan beberapa kegiatan yang lain misalnya mencetak buah semangka dengan alat cetakan dan menyerut buah. 
- Guru berkeliling diantara anakanak yang sedang bermain disentra bahan alam.

- Guru memberikan dukungan berupa pernyataan positif tentang pekerjaan yang dilakukan anak.

- Memancing dengan pertanyaan terbuka untuk memperluas pengetahuan anak.

- Guru memberikan bantuan pada anak yang membutuhkan.

- Guru mendorong anak untuk mencoba dengan cara yang lain, misalnya cara membuat es buah sesuai dengan cara dan seleranya sendiri.

- Mencatat yang dilakukan anak (jenis main, tahap perkembangan, tahap sosial).

- Bila waktu kurang lima menit, memberitahukan kepada anakanak untuk bersiap-siap menyelesaikan kegiatan.

Pijakan Pengalaman Setelah Main (30 menit)

- Bila waktu main habis, memberitahukan saatnya membereskan mainan dengan melibatkan anak-anak.

- Saat membereskan, pendidik menyiapkan tempat yang berbeda untuk setiap jenis alat, sehingga anak dapat mengelompokkan alat main sesuai dengan tempatnya.

- Anak-anak diminta duduk melingkar bersama pendidik.

- Setelah semua anak duduk dalam lingkaran, pendidik menanyakan pada setiap anak kegiatan main yang tadi dilakukannya.

\section{Makan bekal bersama (15 menit)}

- Anak mencuci tangan, berdo'a sebelum makan dan makan bersama.

- Anak membantu untuk membereskan bekas makanan dan membuang bungkus makanan ke tempat sampah.

Kegiatan Akhir / Pijakan Akhir (15 menit)

- Anak berkumpul membentuk lingkaran, bernyanyi lagu "Pedagang es".

- Tepuk Es.

- Bercakap-cakap tentang kegiatan menjadi pedagang es buah yang telah dilakukan hari ini.

- Guru memperlihatkan es buah buatan anak-anak dan memberikan pujian.

- Guru menyampaikan rencana kegiatan hari esok, dan 
menganjurkan anak untuk atau lebih kelompok eksperimen bermain yang sama dirumah yang diberi perlakuan dengan satu masing masing.

- Guru meminta anak yang sudah besar secara bergiliran untuk memimpin do'a penutup.

- Pulang dengan tertib.

\section{METODE PENELITIAN}

Penelitian tentang pengaruh model pembelajaran sentra bahan alam terhadap kemampuan sains dan berbicara pada anak kelompok B di taman kanak-kanak menggunakan pendekatan penelitian kuantitatif dengan metode eksperimen. Penelitian eksperimen menjelaskan bahwa kondisi yang ada dimanipulasi oleh peneliti sesuai dengan kebutuhan peneliti.

Dalam kondisi yang telah dimanipulasi ini, dibuat dua kelompok, yaitu kelompok kontrol dan kelompok pembanding. Kepada kelompok kontrol diberikan treatment atau stimulus tertentu sesuai dengan tujuan penelitian. Hasil dari reaksi kedua kelompok itu yang akan diperbandingkan.

Penelitian ini dilakukan dengan cara membandingkan satu atau lebih kelompok pembanding yang tidak menerima perlakuan.

Tujuan penelitian eksperimen ini untuk mengukur variabel bebas yaitu model pembelajaran sentra bahan alam $(\mathrm{X})$ dan terhadap variabel terikat yaitu kemampuan sains $\left(\mathrm{Y}_{1}\right)$ dan kemampuan berbicara $\left(\mathrm{Y}_{2}\right)$.

Dalam penelitian ini, menggunakan desain penelitian Quasi Eksperimental jenis Nonequivalent Control Group Design dimana terdapat dua kelompok, yaitu kelompok eksperimen dan kelompok kontrol yang tidak dipilih secara random sehingga pada penelitian ini tidak memakai teknik randomization (sampel yang diacak) tetapi menggunakan kelompok yang sudah tersedia di sekolah (Sugiyono, 2011: 79).

Penelitian ini terdiri atas dua kelompok, yaitu kelompok eksperimen dan kelompok kontrol yang dimaksudkan untuk membandingkan kemampuan sains dan kemampuan berbicara pada 
kelompok eksperimen yang diberikan perlakuan berupa model pembelajaran sentra bahan alam melalui kegiatan menjadi penjual dan pembeli es buah, pada kelompok kontrol tidak diberikan perlakuan menggunakan model pembelajaran sentra bahan alam melalui kegiatan menjadi penjual dan pembeli es buah. Untuk mengetahui kondisi awal kedua kelompok, dilakukan observasi awal kepada kedua kelompok. Setelah dilakukan observasi awal, kelompok eksperimen diberikan perlakuan sedangkan kelompok kontrol tidak diberikan. Kemudian dilakukan observasi akhir untuk mengetahui kemampuan sains dan berbicara sesudah diberikan perlakuan.

Populasi penelitian ini adalah seluruh populasi anak kelompok B usia 5-6 tahun di TK PGRI 3 Pandaan Kabupaten Pasuruan dan TK PKK V Pandaan Kabupaten Pasuruan. Jumlah seluruh populasi penelitian kelompok eksperimen sejumlah 44 anak sedangkan kelompok kontrol sejumlah 40 anak.

Dalam penelitian ini tidak menggunakan sampel dikarenakan penelitian ini adalah penelitian populasi. Artinya semua populasi dijadikan subjek penelitian.

Metode pengumpulan data adalah cara-cara yang dapat digunakan oleh peneliti untuk mengumpulan data (Arikunto, 2010: 101). Instrumen pengumpulan data adalah alat bantu yang dipilih dan digunakan oleh peneliti dalam kegiatannya mengumpulkan data agar kegiatan tersebut menjadi sistematis dan lebih mudah. Dalam penelitian ini menggunakan teknik pengumpulan data dengan observasi dan dokumentasi.

Teknis analisis data yang digunakan untuk menguji hipotesis pertama dan kedua digunakan uji One Way Anova, sedangkan hipotesis ketiga digunakan uji multivariate analysis of varience (MANOVA) yaitu uji untuk melihat bagaimanakah pengaruh semua variabel terikatnya. Uji MANOVA digunakan dalam penelitian ini membandingkan dua variabel yaitu kemampuan sains dan kemampuan berbicara. Pengujian hipotesis ini dengan menggunakan bantuan SPSS 21.0 for Windows Evaluation Version. Namun sebelum 
itu, terlebih dahulu dilakukan uji homogenitas dan uji normalitas.

\section{HASIL PENELITIAN DAN PEMBAHASAN}

\section{A. Pengaruh model pembelajaran sentra bahan alam terhadap kemampuan sains anak kelompok B di Taman Kanak- kanak}

Hipotesis pertama yakni ada pengaruh model pembelajaran sentra bahan alam terhadap kemampuan sains. Untuk menguji hipotesis pertama digunakan uji one way analysis of variance (ANOVA) adapun hasil analisisnya sebagai berikut:

Tabel 1

Hasil uji ANOVA kemampuan sains

\begin{tabular}{r|cc}
\hline \multicolumn{1}{c|}{ Variabel Kemampuan Sains } & Nilai rata-rata & Standar Deviasi \\
\hline Post-test kelompok kontrol & 16,28 & \\
Post-test kelompok eksperimen & 20,95 & 1,881 \\
& & 1,462 \\
\hline F-hitung & 163,661 & \\
Sig & 0,000 & \\
\hline
\end{tabular}

Hasil uji F-hitung yang dihasilkan sebesar 163,661 dengan tingkat signifikasi (sig) kurang dari 5\%, yang berarti bahwa ada perbedaan kemampuan sains yang signifikan antara kelompok kontrol dan kelompok eksperimen, sehingga hipotesis ke-1 dapat diterima. Dapat disimpulkan bahwa model pembelajaran sentra bahan alam berpengaruh terhadap kemampuan sains.

Adapun kegiatan yang dilakukan di kelompok eksperimen melalui model pembelajaran sentra bahan alam untuk menstimulasi kemampuan sains yaitu anak bermain aktif menjadi penjual dan pembeli es buah, membuat es buah sendiri dengan mencampurkan berbagai macam buah, air dan sirup,anak terlihat senang menikmati hasil es buah buatannya sendiri. Selain itu anak juga melakukan kegiatan mencetak buah semangka, melon, dan pepaya, mengelompokkan benda sesuai dengan fungsi misalya gelas, sendok, 
mangkuk, serta mengamati proseses mencair.

$$
\text { Dalam melaksanakan }
$$

kegiatan bermain di sentra bahan alam, anak terlihat sangat senang dan aktif menjadi penjual es buah. Beberapa anak sangat kritis bertanya dan merasa takjub ketika melakukan percobaan es yang lebih mudah mencair bila dimasukkan ke dalam air dan diaduk kemudian anak dapat langsung menikmatinya. Selain itu anak dapat melakukan dengan caranya sendiri, yaitu digesekkan dengan kedua tangannya, disisi lain es dibiarkan begitu saja di gelas. Kegiatan eksplorasi yang dilakukan anak-anak ini mendukung pemikiran Bruner (dalam Yulianti, 2010:32) yang mengemukakan bahwa bermain mendorong anak melakukan berbagai kegiatan dalam memecahkan berbagai permasalahan melalui penemuan.

Penelitian tentang model pembelajaran sentra bahan alam ini juga membenarkan pandangan Mayesky (dalam Asmawati, 2008:8.3) yang mengemukakan bahwa sentra mempunyai keterkaitan yang kuat dengan beberapa pandangan ahli pendidikan, seperti Pestalozzi yang percaya bahwa anakanak belajar melalui interaksi langsung dengan anak lain dan lingkungannya, John Dewey dengan penekanannya pada "belajar sambil bekerja" dan "hubungan organik antara pendidikan dan pengalaman seseorang",serta Montessori dengan pemikirannya bahwa anak kecil belajar melalui tugas-tugas dan alatalat belajar yang disiapkan dengan hati-hati.

Kegiatan yang dilakukan dalam penelitian ini membenarkan teori konstruktivisme yang dikemukakan Sagala (2003:44) menyatakan bahwa dengan memanfaatkan lingkungan sebagai sumber belajar dimana anak didorong untuk bereksplorasi dengan jalan menemukan suatu penemuan dan memecahkan hasil penemuan itu. Aktivitas kegiatan melalui model pembelajaran sentra bahan alam memiliki peran yang cukup besar dalam mengembangkan kemampuan sains pada anak usia dini. 
B. Pengaruh model pembelajaran sentra bahan alam terhadap kemampuan berbicara anak kelompok B di Taman Kanakkanak

Hipotesis kedua yakni ada pengaruh model pembelajaran sentra bahan alam terhadap kemampuan berbicara. Untuk menguji hipotesis kedua digunakan uji one way analysis of variance (ANOVA) adapun hasil analisisnya sebagai berikut:

Tabel 2

Hasil uji ANOVA kemampuan berbicara

\begin{tabular}{r|ll}
\hline \multicolumn{1}{c|}{$\begin{array}{c}\text { Variabel Kemampuan } \\
\text { Berbicara }\end{array}$} & \multicolumn{1}{|c}{$\begin{array}{c}\text { Nilai rata- } \\
\text { rata }\end{array}$} & Standar Deviasi \\
\hline Post-test kelompok kontrol & 10,53 & \\
Post-test kelompok eksperimen & 12,43 & 1,086 \\
& & 1,129 \\
\hline F-hitung & 61,992 & \\
Sig & 0,000 & \\
\hline
\end{tabular}

Hasil uji F yang dihasilkan sebesar 61,992 dengan tingkat signifikasi (sig) kurang dari 5\%, yang berarti bahwa ada perbedaan kemampuan berbicara yang signifikan antara kelompok kontrol dan kelompok eksperimen, sehingga hipotesis ke-2 dapat diterima. Dapat disimpulkan bahwa model pembelajaran sentra bahan alam berpengaruh terhadap kemampuan berbicara.

Ketika observasi berlangsung, terdapat kemampuan berbicara yang muncul secara spontan antara penjual dan pembeli yaituketika anak menawar harga es buah yang dijual " beli seribu esnya!", anak memilih buah yang disukainya "aku mau buahnya semangka dan nanas", mengungkapkan rasa es buah yang dimakannya "mmm, enak sekali, mantap", anak sebagai penjual menyuruh antri dengan tertib “ belinya antri ya!", kemudian mempersilahkan pembeli untuk menikmati “ini silahkan diminum!”, "semangkaku lebih banyak, pepayamu lebih sedikit". Terjadi komunikasi anak bersama temannya saat melakukan percobaan sederhana 
bagaimana es mudah mencair, saat mengingatkan temannya langkahlangkah yang dilakukan agar dapat melakukan percobaan itu, "esnya dikasih air, sirup, terus diaduk".

Hasil observasi yang dilakukan dapat disimpulkan kegiatan dalam model pembelajaran sentra bahan alam ini dapat merangsang anak untuk berkomunikasi dengan temannya, bertanya, mengungkapkan ide dan pendapatnya, sehingga kemampuan anak dalam berbicara akan semakin berkembang. Penelitian model pembelajaran sentra bahan alam ini mendukung pendapat Chaer (2006:226) bahwa perkembangan bahasa berkaitan dengan perkembangan sosial dan komunikasi.

Interaksi yang terjadi saat anak melakukan kegiatan sebagai penjual dan pembeli juga sesuai dengan teori Vygotsky (dalam Montolalu, 2014:1.9) yang berpendapat bahwa bentuk bahasa pada dasarnya bersifat sosial. Pengetahuan dibangun secara sosial, artinya menekankan pemusatan hubungan sosial sebagai hal penting yang mempengaruhi perkembangan kognitif, karena pertama-tama anak menemukan pengetahuan dalam dunia sosialnya, kemudian menjadi bagian dari perkembangan kognitifnya.

\section{Pengaruh model pembelajaran} sentra bahan alam terhadap kemampuan sains dan berbicara anak kelompok B di Taman Kanak-kanak

Hipotesis ketiga adalah terdapat pengaruh model pembelajaran sentra bahan alam terhadap kemampuan sains dan berbicara dengan anak. Untuk menguji hipotesis tersebut digunakan anaisis varians multivriate (MANOVA). Adapun hasil analisisnya sebagai berikut: 
Pengaruh Model Pembelajaran .......

Ajeng Putri Pratiwi, Rika Kurnia,

Nopiana

Tabel 3

Hasil uji hipotesis dengan MANOVA

Multivariate Tests

\begin{tabular}{|ll|r|r|r|r|r|}
\hline Effect & & \multicolumn{1}{|c|}{ Value } & \multicolumn{1}{c|}{$\mathrm{F}$} & Hypothesis df & \multicolumn{1}{c|}{ Error df } & \multicolumn{1}{c|}{ Sig. } \\
\hline Intercept & Pillai's Trace & .994 & $7058.934^{\mathrm{a}}$ & 2.000 & 81.000 & .000 \\
& Wilks' Lambda & .006 & $7058.934^{\mathrm{a}}$ & 2.000 & 81.000 & .000 \\
& Hotelling's Trace & 174.295 & $7058.934^{\mathrm{a}}$ & 2.000 & 81.000 & .000 \\
& Roy's Largest Root & 174.295 & $7058.934^{\mathrm{a}}$ & 2.000 & 81.000 & .000 \\
\hline kelas & Pillai's Trace & .683 & $87.091^{\mathrm{a}}$ & 2.000 & 81.000 & .000 \\
& Wilks' Lambda & .317 & $87.091^{\mathrm{a}}$ & 2.000 & 81.000 & .000 \\
& Hotelling's Trace & 2.150 & $87.091^{\mathrm{a}}$ & 2.000 & 81.000 & .000 \\
& Roy's Largest Root & 2.150 & $87.091^{\mathrm{a}}$ & 2.000 & 81.000 & .000 \\
\hline
\end{tabular}

a. Exact statistic

b. Design: Intercept+kelas

Berdasarkan hasil uji

multivariate seperti yang disajikan pada tabel di atas diperoleh Nilai wilks'lambda sebesar 0,317 dengan taraf signifikasi kurang dari 5\% yaitu sebesar 0,000 . Hal ini berarti variabel kemampuan sains dan kemampuan berbicara secara bersama-sama menunjukkan perbedaan yang signifikan antara kelompok kontrol dan kelompok eksperimen, sehingga hipotesis ke-3 dapat diterima. Dapat disimpulkan bahwa model pembelajaran sentra bahan alam berpengaruh terhadap kemampuan sains dan kemampuan berbicara.

Melalui kegiatan menjadi penjual dan pembeli es buah, mengajak anak bermain aktif melakukan percobaan sederhana, hal ini sangat penting dalam mengoptimalkan kemampuan sains anak usia dini. Pentingnya anak bermain sains didukung oleh penelitian Eshach dan Fried (dalam Trundle, 2009) menyatakan bahwa pembelajaran sains pada anak usia dini sangat penting untuk aspek perkembangannya dan pendidikan anak usia dini merupakan awal bagi mereka untuk belajar sains.

Model pembelajaran sentra bahan alam dapat mengembangkan kemampuan berbicara anak usia dini melalui kegiatan bermain menjadi penjual dan pembeli es buah. Dalam kegiatan ini anak dapat bertanya dan menjawab pertanyaan, mengungkapkan keinginan dan pendapatnya sehingga kemampuannya dalam berbicara semakin berkembang. Kegiatan dalam menceritakan pengalamannya 
membuat es buah sendiri selaras dengan pendapat Piaget (dalam Dhieni, 2013:2.15) yang berpikir sebagai prasarat berbahasa, terus berkembang sebagai hasil pengalaman dan penalaran.

Kemampuan berbicara anak semakin berkembang melalui pengalaman konkrit dan bermakna.

\section{SIMPULAN}

Dari hasil penelitian dan pembahasan pada bab-bab sebelumnya dan sesuai dengan tujuan penelitian ini, maka pada bab ini akan dirumuskan beberapa simpulan dan saran yang berkaitan dengan pengaruh model pembelajaran sentra bahan alam terhadap kemampuan sains dan berbicara, sebagai berikut:

1. Model pembelajaran sentra bahan alam berpengaruh terhadap kemampuan sains. Terdapat perbedaan kemampuan sains antara kelompok kontrol dan kelompok eksperimen, yaitu kemampuan sains pada kelompok eksperimen lebih baik daripada kelompok kontrol, yang dilihat dari nilai rata-rata kemampuan sains pada kelompok kontrol sebesar10,53 dan masuk dalam kategori berkembang sesuai harapan dan nilai rata-rata kemampuan sains pada kelompok eksperimen sebesar sebesar 20,95 dan masuk dalam kategori berkembang sangat baik.

2. Model pembelajaran sentra bahan alam berpengaruh terhadap kemampuan berbicara. Terdapat perbedaan kemampuan berbicara antara kelompok kontrol dan kelompok eksperimen, yaitu kemampuan berbicara pada kelompok eksperimen lebih baik dari kelompok kontrol, hal ini dilihat dari nilai rata-rata kemampuan berbicara pada kelompok kontrol sebesar 10,53 dan masuk dalam kategori berkembang sesuai harapan dan nilai rata-rata kemampuan berbicara pada kelompok eksperimen sebesar 12,43 dan masuk dalam kategori berkembang sesuai harapan. Walaupun kedua kelompok masuk dalam kategori mampu tanpa bimbingan guru tetapi kedua nilai tersebut adalah berbeda secara signifikan. 
3. Model pembelajaran sentra bahan alam berpengaruh terhadap kemampuan sains dan berbicara. Variabel kemampuan sains dan kemampuan berbicara secara bersama-sama menunjukkan perbedaan antara kelompok kontrol dan kelompok eksperimen.

\section{DAFTAR PUSTAKA}

Arikunto, Suharsimi. 2010. Prosedur Penelitian (Suatu Pendekatan Praktik). Yogyakarta: Rineka Cipta.

Asmawati, Luluk. 2008. Pengelolaan Kegiatan Pengembangan Anak Usia Dini. Jakarta: Universitas Terbuka

Chaer. 2006. Psikolinguistik: Kajian Teoretik. Jakarta: Rineka Cipta.

Depdiknas. 2003. Undang-Undang RI

No. 20. Tentang Sistem Pendidikan Nasional. Jakarta: Depdiknas.

Depdiknas. 2007. Pedoman Penerapan Pendekatan "Beyond Centers And Circle Time (BCCT)" (Pendekatan Sentra dan Saat Lingkaran)
Dalam Pendidikan Anak Usia

Dini. Jakarta: Direktorat

Pendidikan dan Tenaga

Kependidikan Pendidikan

Nonformal.

Depdiknas. 2007. Pedoman

Pembelajaran Bidang

Pengembangan Berbahasa.

Jakarta: Depdiknas.

Dhieni, Nurbiana. 2013. Metode

Pengembangan Bahasa.

Jakarta: Universitas Terbuka.

Jackman, Hilda L. 2012. Early

Education Curriculum A

Child's Connection to The

World. United States of America: Wadsworth, Change Learning.

Kalliala, M. 2006. Play Culture in a changing world. England: Open University Press.

Kementrian Pendidikan Nasional. 2011. Peraturan Menteri Pendidikan Nasional Republik Indonesia Nomor 58 Tahun $2009 \quad$ Tentang Pendidikan Anak Usia Dini. Jakarta..

Morrison, George S. 2012. DasarDasar Pendidikan Anak Usia Dini (PAUD) Jakarta: Indeks. 
Montolalu. 2005. Bermain dan Permainan Anak. Jakarta: Universitas Terbuka.

Program Pascasarjana Universitas Negeri Surabaya. 2014.

Pedoman Penulisan Tesis dan Disertasi Program Pascasarjana UNESA. Surabaya: Unesa.

Sagala, Syaiful. 2003. Konsep dan Makna Pembelajaran.

Bandung: Alfabeta.

Seefeld, Carool \& Wasik, Barbara A. 2008. Pendidikan Anak Usia Dini. Jakarta: Indeks Sugiyono, 2012. Metode Penelitian Kuantitatif. Kualitatif dan $R \& D$. Bandung: Alfabeta.

Sujiono, Yuliani Nurani dan Sujiono, Bambang. 2010. Bermain Kreatif Berbasis Kecerdasan Jamak. Jakarta: Indeks.

Sutama, I Wayan dan Budhojo, Kentar. 2010. Modul Pengembangan Materi Umum Model Pembeljaran PAUD. Malang: Universitas Negeri Malang.

Sutama, I Wayan dkk. 2010. Bidang Pengembangan di Taman-
Kanak-kanak. Malang:

Universitas Negeri Malang.

Trundle, Kathy Cabe. 2009. Teaching Science During The Early Childhood Years.(http//ngl.cengage.com/ images/advertisments/marketi ng_download/PRO00000000 28/SCL220429A_AM_Trundle.pdf,_dia kses 20 Desember 2014)

Winataputra, Udin S. 2011. Teori Belajar dan Pembelajaran. Jakarta: Universitas Terbuka. 